NAMA : EVAN SUTANTO

NRP: 130217056

$\mathrm{KP}: \mathrm{B}$

\title{
TUGAS PEREKONOMIAN INDONESIA
}

Pariwisata di Indonesia merupakan salah satu dorongan untuk meningkatkan ekonomi di Indonesia. Tur Dunia dan Travel Council (2016) menyarankan bahwa sektor pariwisata di Indonesia berkontribusi 9,8\% terhadap Produk Domestik Bruto. Dan Badan Pusat Statistik (2016) menjelaskan bahwa sektor pariwisata memberikan kontribusi 4\% terhadap Produk Domestik Bruto. Selain itu, jumlah perjalanan pariwisata domestic pada tahun 2011 hingga 2015 memiliki peningkatan rata - rata sebesar 1,93\% dan jumlah pengeluaran wisatawan domestik pada tahun 2011 rata-rata adalah Rp669,58 ribu, dan Rp880,94 ribu pada tahun 2015. Selain itu, Kedatangan wisatawan asing ke Indonesia pada bulan Januari - Oktober 2016 mencapai 9,4 juta, dan jumlah ini lebih tinggi 9,54\% dari jumlah kedatangan pada bulan Januari - Oktober 2015 sebanyak 8,78 juta.

Di tahun 2016 Indonesia memiliki peluang besar untuk meningkatkan pariwisata, karena Asia menjadi daerah tujuan wisata dunia. Sekitar 300 juta wisatawan telah datang ke Asia, sepertiga atau 100 juta dari mereka mengunjungi wilayah Asia Tenggara, terutama seperti, Singapura, Thailand, Malaysia, dan Indonesia. Obyek wisata yang di tawarkan Indonesia sebenarnya lebih menarik daripada Singapura, Malaysia, dan Thailand. Sebagai contoh : Raja Ampat di Papua yang menawarkan wisata yang sangan menakjubkan, yaitu pantai nya dan keindahan alam lainnya. Namun di sisi lain, untuk ke Raja Ampat, memakan biaya yang lumayan besar, seperti tiket pesawat yang lumayan mahal, akomodasi seperti hotel, dan kapal untuk mengunjungi pulau-pulau yang menjadi destinasi pariwisata popular di Raja Ampat.

Selain destinasi pariwisata yang ada di Indoneisa, hal lain yang menarik juga yaitu, warisan budaya Indonesia seperti, Candi Borobudur salah satu candi yang masuk dalam 7 keajaiban dunia), Candi Prambanan, rumah adat, tarian Jawa, 
dan Bali yang sangat popular. Dalam pengembangan terhadap destinasi pariwisata di Indonesia juga melibatkan Industri Kreatif yang memberikan peran yang sangat luas dalam meningkatkan citra pariwisata. Kreativitas berbasis ilmu pengetahuan, seperti desain, tarian dan lagu, secara langsung berhubungan dengan ilmu pemasaran, seperti promosi, pencitraan, branding, yang mampu mengelola strategi pemasaran dari pendekatan emosional konsumen. Selain itu Ekonomi Kreatif juga dapat membantu dalam meningkatkan konteks warisan budaya Indonesia agar semakin di kenal oleh wisatawan asing dan domestic dengan menyebarkan pengalaman melalui cerita dari mulut ke mulut tentang kota yang unik perencanaan, upacara tradisional, arsitektur hotel, ragam kuliner, souvenir, dan lainnya.

Dalam pengembangan destinasi pariwisata dan warisan budaya di negara Indonesia untuk Ekonomi Kreatif yaitu menggunakan penelitian yang berbasis deskriptif kualitatif. Penelitian ini menggunakan data primer yang berasal dari wawancara dengan para pemangku kepentingan dan observasi objek wisata yang dikelola oleh masyarakat di Jawa Timur, Yogyakarta dan Jawa Tengah. Selanjutnya, data sekunder diperoleh dari Kementerian Pariwisata dan Ekonomi Kreatif Republik Indonesia dan harian Kompas.

Pariwisata Indoneisa juga tidak hanya untuk meningkatkan Produk Domestik Bruto, tetapi juga sebagai penghasil devisa dan penjaga stabilitas mata uang Indonesia terhadap mata uang asing. Pariwisata juga harus di dorong untuk dapat menutupi kesenjangan yang ditinggalkan oleh sektor minyak, gas, dan batubara yang pada gilirannya dapat meningkatkan kontribusi pariwisata dan ekonomi kreatif terhadap Produk Domestik Bruto, karena pariwisata adalah salah satu asset berharga yang di miliki negara Indonesia.

Pemerintah juga telah memprioritaskan 10 destinasi/tujuan wisata di Indonesia agar pertumbuhan ekonomi dapat merata, dan para wisatawan asing maupun domestic dapat memiliki alternative untuk menikmati liburan di Indonesia. Pengembangan tujuan wisata yaitu dengan pembukaan penerbangan dari beberapa maskapai untuk tunjuan seperti Labuan Bajo di Nusa Tenggara Timur, dan Wakatobi di Sulawesi Tenggara. Maskapai yang telah membuka penerbangan ini 
yaitu maskapai Garuda Indonesia dan Lion Group. Keberanian maskapai untuk membuka rute baru mampu mendongkrak jumlah wisatawan domestik dan asing untuk mengunjungi destinasi wisata yang diprioritaskan yang pada gilirannya akan meningkatkan tingkat hunian kamar hotel bintang lima, termasuk hotel yang diberi peringkat bintang 2 atau 3 .

Selain itu, keberadaan operator dalam jaringan Internet sangat membantu dalam meningkatkan potensi pariwisata Indonesia seperti Bali, Lombok, Yogyakarta, Bandung, dan Danau Toba yang belum dikenal secara luas oleh wisatawan asing. Kini, dengan semakin banyaknya operator pariwisata yang menjual jasa melalui Internet membuat destinasi wisata yang tidak dikenal menjadi populer dan dikunjungi banyak wisatawan, seperti Tanjung Kelayang, Mandalika, dan Pulau Morotai.

Dengan adanya operator Internet, alternative yang perlu di tingkatkan untuk mempromosikan pariwisata di Indonesia yaitu dengan media sosial dan promosi MICE (Rapat, Insentif, Konvensi, dan Pameran) karena dapat menjadi titik masuk bagi orang asing yang mengunjungi Indonesia untuk tujuan bisnis, dan umumnya tidak datang sendiri. Pengusaha asing diharapkan mengisi menghabiskan waktu dengan berbelanja, mengunjungi objek wisata (City Tour), dan membeli produk kreatif lokal untuk dibawa ke negara mereka dan bisa di sebarkan dari mulut ke mulut.

CITATION: Tayibnapis, A.Z. \& Wuryaningsih, L.E. (2017). Development of Tourism and Creative Industry in Indonesia, Surabaya : Department on Management, Faculty of Business and Economics Universitas Surabaya 
